\title{
Arylphosphonate-tethered porphyrins: Fluorescence silencing speaks a metal language in living enterocytes
}

\author{
Claudia Keill, ${ }^{[a]}$ Julia Klein, ${ }^{[a]}$ Franz-Josef Schmitt,${ }^{[b]}$ Yunus Zorlu, ${ }^{[c]}$ Hajo Haase,${ }^{*[a]}$ Gündoğ Yücesan ${ }^{*[a]}$
}

[a] Dr. Claudia Keil, Julia Klein, Prof. Dr. Hajo Haase, Dr. Gündoğ Yücesan.

Technische Universität Berlin, Chair of Food Chemistry and Toxicology,

Straße des 17. Juni 135, 10623 Berlin, Germany

E-mail: yuecesan@tu-berlin.de and haase@tu-berlin.de

[b] Dr. Franz-Josef Schmitt

Martin-Luther-Universität Halle-Wittenberg, 06120, Halle (Saale), Germany

[c] Dr. Yunus Zorlu,

Department of Chemistry, Faculty of Science

Gebze Technical University

41400, Gebze-Kocaeli

Supporting information for this article is given via a link at the end of the document.

\begin{abstract}
We report the application of a highly versatile and engineerable novel sensor platform to monitor biologically significant and toxic metal ions in live human Caco-2 enterocytes. The extended conjugation between the fluorescent porphyrin core and metal ions via aromatic phenylphosphonic acid tethers generates a unique turn off and turn on fluorescence and, in addition, shifts in absorption and emission spectra for zinc, cobalt, cadmium and mercury. The reported fluorescent probes $p-\mathrm{H}_{8}$ TPPA and $m-\mathrm{H}_{8}$ TPPA can monitor a wide range of metal ion concentrations via fluorescence titration and also via fluorescence decay curves. $\mathrm{Cu}$ and $\mathrm{Zn}$-induced turn off fluorescence can be differentially reversed by the addition of common chelators. Both $p-\mathrm{H}_{8}$ TPPA and $m-\mathrm{H}_{8}$ TPPA readily pass the mammalian cellular membrane due to their amphipathic character as confirmed by confocal microscopic imaging of living enterocytes.
\end{abstract}

\section{Introduction}

Nearly half of all cellular proteins require one or more metal ions as cofactors (transition metals to alkali and alkaline-earth metals) to perform their functions ${ }^{[1]}$. Metal ions are present in all 6 classes of enzymes ${ }^{[2]}$ and metalloproteins assume significant roles in signal transduction ${ }^{[3-6]}$. Therefore, the distribution of metal ions in biology is very tightly regulated through a complex network of interactions ensuring proper metal ion homeostasis [7,8]. Disturbance or mutations in the metabolic pathways of metal ion homeostasis could produce significant disarray in signal transduction or impede other biochemical pathways [3-6,9], resulting in cellular damage or even death, e.g., by apoptosis ${ }^{10-}$ ${ }^{12]}$, and promote diseases such as cancer [13], diabetes [14-16], vascular ${ }^{[17]}$ or soft tissue calcifications ${ }^{[18]}$ and Alzheimer's disease ${ }^{[19-21]}$. Therefore, monitoring the concentrations of metal ions in living systems is crucial to provide diagnosis and treatment of innumerous metabolic disorders as well as to understand the mechanism of how metal ions are regulated ${ }^{[22-24]}$.

Despite the importance of metal ions in biology, there are still only a few methods to monitor free or unbound metal ion concentrations; among them, fluorescent imaging is one of the most suitable techniques [25-27]. Small molecule fluorescent sensors could generate response upon metal binding ${ }^{[24,28-31]}$ or protein and peptide-based systems mobilize fluorescent compartments to produce FRET fluorescence upon metal binding [32-35]. However, the number of such fluorescent probes is limited, and design routes to create metal ion responsive fluorescence are not yet well-established. The ideal fluorescent probe to detect metal ions should provide dynamic electronic interactions between the fluorescent core and the metal ion to cause a detectable change in fluorescence. To this end, the metal sensing unit of the fluorescent probe should be directly attached to at least one of the $\mathrm{sp}^{2}$ carbon atoms to produce extended conjugation interacting with the target metal. In contrast, $\mathrm{sp}^{3}$ bonded metal sensing units could carry the fluorescent tag to a targeted area without altering the fluorescent signal upon metal binding. We have recently shown that such a design strategy in extending the conjugation of the fluorescent core allows direct electronic interactions with rat bone sections, in return producing turn up fluorescence upon hydroxyapatite binding using $p$ - $\mathrm{H}_{8}$ TPPA and $m-\mathrm{H}_{8}$ TPPA fluorescent probes ${ }^{[36]}$, with toxicity studies indicating that $p-\mathrm{H}_{8}$ TPPA was well tolerated by an intestinal cell line ${ }^{[37]}$. Phenylphosphonic acid tethers provide 1.7 and 7.4 pKa1 and pKa2 values, respectively ${ }^{[38,39]}$, and each of the phenylphosphonic acid tethers are expected to provide -2 negative charge at physiological $\mathrm{pH}$. Therefore, phosphonic acid derivatives could be used to generate ionic interactions with divalent metal ions in biological systems, but their use as metal sensing units has been neglected due to difficult and limited synthetic routes, especially due to the challenge of forming P-C bonds in conjugated fluorescent systems. Consequently, the number of aromatic phosphonic acids in the literature are still quite limited [39-43]. To further understand the metal-induced fluorescence change observed in rat bone sections, we continued using arylphosphonic acids in Scheme 1, from left to right, 5,10,15,20-tetrakis [ $m$-phenylphosphonic acid] porphyrin ( $\boldsymbol{m}$ $\mathrm{H}_{8}$ TPPA), its positional isomer 5,10,15,20-Tetrakis [pphenylphosphonic acid] porphyrin $\left(\boldsymbol{p}\right.$ - $\mathrm{H}_{8}$ TPPA), and the ester 


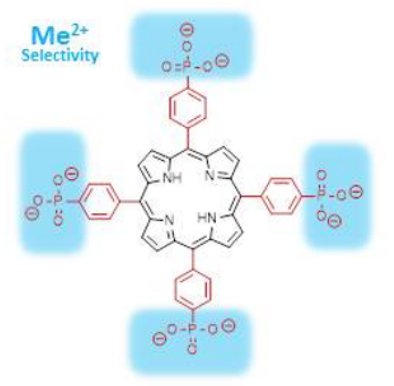

form5,10,15,20-tetrakis-[p-(diisopropoxyphosphoryl)phenyl] porphyrin $\left(\boldsymbol{p}-\mathrm{H}_{8} \text { TPPA-iPr}\right)_{8}$; this time to create a differentially altered fluorescence upon binding to metal ions. For this study, we have selected a range of biologically relevant metal ions and toxic heavy metals. We have observed a wide variety of unique fluorescent responses upon binding of the fluorophores with the biologically relevant metal ions $\mathrm{Zn}, \mathrm{Cu}, \mathrm{Co}, \mathrm{Ni}, \mathrm{Fe}, \mathrm{Mn}, \mathrm{Mg}, \mathrm{Ca}$, and toxic metal ions $\mathrm{Cd}, \mathrm{Pb}, \mathrm{Hg}$, and $\mathrm{Co}$ in Caco-2 cells. We intentionally inhibited the extended conjugation of the fluorescent core ( $\boldsymbol{p}-\mathrm{H}_{8}$ TPPA) and the metal ion binding by using the isopropyl diester ( $\boldsymbol{p}$ - $\mathrm{H}_{8}$ TPPA-iPrs), which showed no fluorescence change upon metal binding.

\section{Results and Discussion}

Aiming to use arylphosphonate-tethered porphyrins as realtime cellular metal fluorescence sensors, we first characterized their metal-responsiveness under cell-free

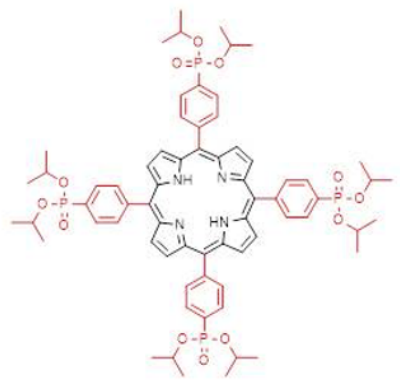

conditions. $p-\mathrm{H}_{8}$ TPPA (see Fig. 1) and $m-\mathrm{H}_{8}$ TPPA (see Suppl Fig. 1), were pretreated with various bivalent metal ions at a $\mathrm{pH}$ close to the cellular milieu $(\mathrm{pH} 7.4)$ before recording absorption and fluorescence spectra. The visible absorption of both sensors in the buffer-control treatment showed maxima in the range of $380-430 \mathrm{~nm}$, with a typical Soret peak at around $416 \mathrm{~nm}$, already observed in our recent studies ${ }^{[36,44]}$ and also by others ${ }^{[45]}$. $\mathrm{Ca}^{2+}$ or $\mathrm{Mg}^{2+}$ treatment did not shift the position of the Soret maximum, but slightly raised the intensity of the absorption spectrum causing a higher fluorescence, characteristic for non-ratiometric metalON fluorescence sensors. This observation confirms our recent results of $\mathrm{H}_{8}$ TPPA and $m-\mathrm{H}_{8}$ TPPA fluorescence enhancement in the presence of calcium-hydroxyapatite phases or bones ${ }^{[36]}$. $\mathrm{Mn}^{2+}$, and far more pronounced $\mathrm{Pb}^{2+}$, narrowed non-ratiometrically the photon absorbing properties of $\mathrm{p}-\mathrm{H}_{8}$ TPPA and $\mathrm{m}-\mathrm{H}_{8}$ TPPA, thus their fluorescence dropped markedly.
A) Absorbance scan
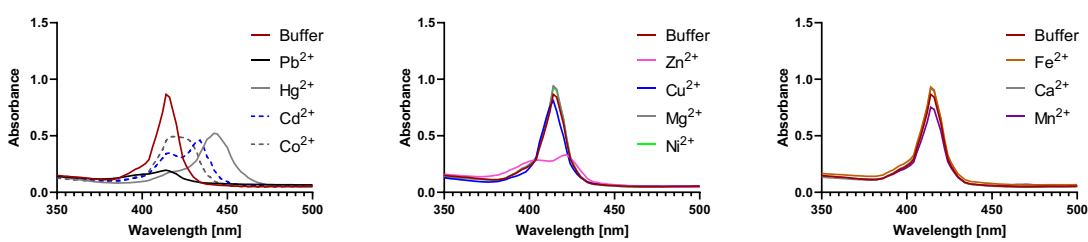

B)
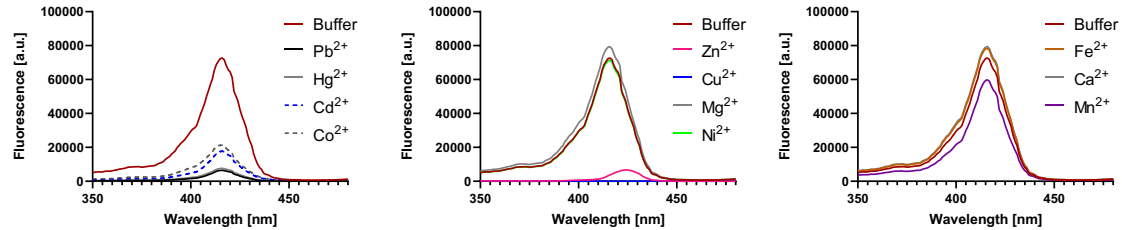

C) Fluorescence Emission spectrum

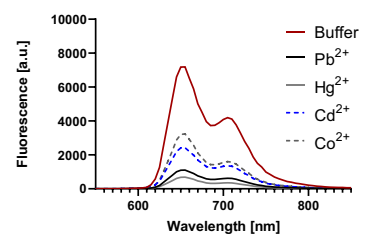

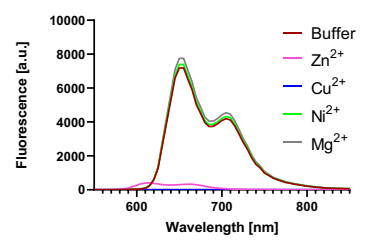

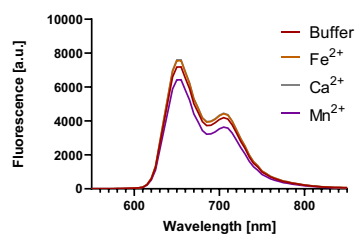

Fig. 1 Metal-dependent changes of $p$ - $\mathrm{H}_{8}$ TPPA absorbance and fluorescence properties.

$10 \mu \mathrm{M} p-\mathrm{H}_{8}$ TPPA dilutions were treated with various metal solutions (final concentration $40 \mu \mathrm{M}$ ) before recording (A) absorbance, (B) fluorescence excitation $\left(\lambda_{\mathrm{Em}} .650 \mathrm{~nm}\right)$ and $(C)$ fluorescence emission ( $\lambda_{\mathrm{Exc} .} 415 \mathrm{~nm}$ ) spectra. Data are representative for three independent experiments. 
The $\mathrm{Cd}^{2+}$-treated sensors showed a decline of the $416 \mathrm{~nm}$ absorbance maximum and the appearance of a new band peaking at $434 \mathrm{~nm}$. Following $\mathrm{Co}^{2+}$ treatment absorption spectra were less intense, plateau-shaped with a bathochromic broadening up to $434 \mathrm{~nm}$. $\mathrm{Hg}^{2+}$-treatment redshifted the Soret band by approximately $30 \mathrm{~nm}$. Albeit that, none of the absorption shifts led to comparable shifts in the emission bands. Despite of their restricted fluorescence intensity, the fluorescence emission patterns of all the aforementioned metal-treated arylphosphonate-tethered porphyrins seemed to be completely distinct und almost indistinguishable from the buffer-controls (see Fig. 1C, Suppl Fig. 1 and 3 ). $\mathrm{Zn}^{2+}$ treatment led to a declined and much more broadened Soret band in the range of $380-430 \mathrm{~nm}$ (see Fig. 1A). Still, the fluorescence emission was much lower than what would have been expected from the fluorescence excitation properties (see Fig. 1B and C). Thus, we assume a fluorescence quenching effect of $\mathrm{Zn}^{2+}$ that requires further investigation.

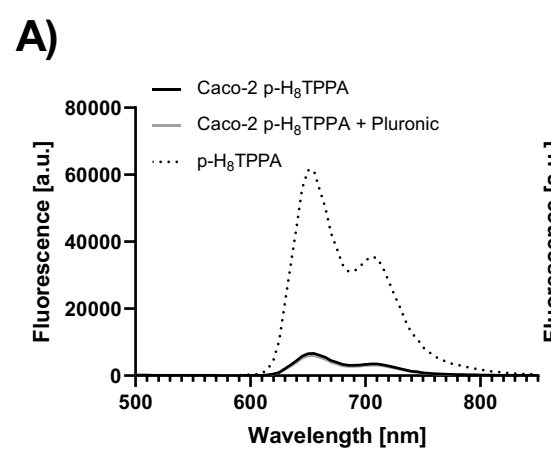

B)

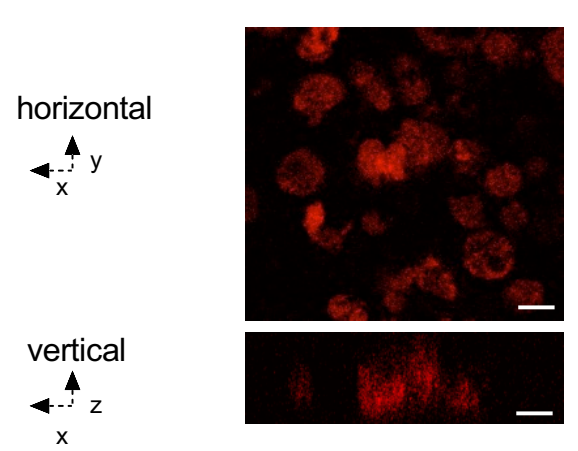

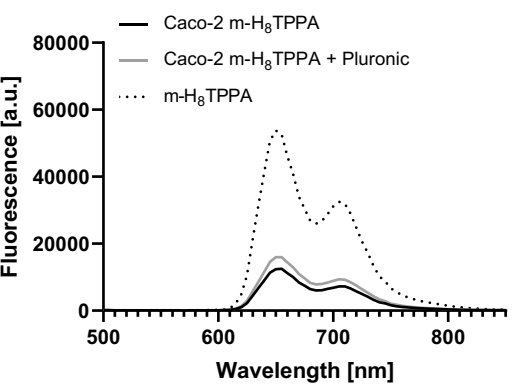

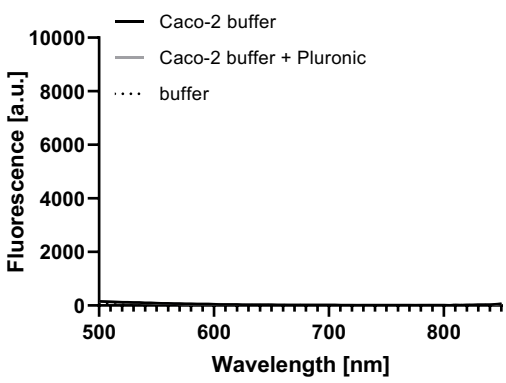

Caco-2

buffer
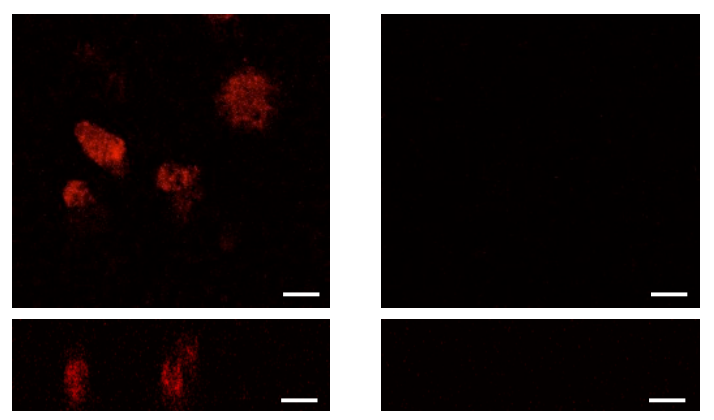

C)

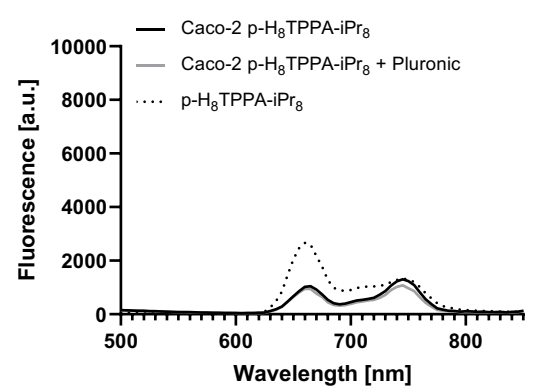

D)

\section{Caco-2 $\mathrm{p}-\mathrm{H}_{8}$ TPPA-iPr}

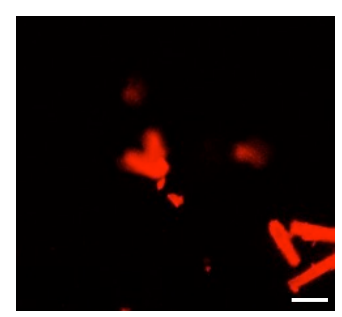

$\mathrm{p}-\mathrm{H}_{8} \mathrm{TPPA}-\mathrm{PPr}_{8}$

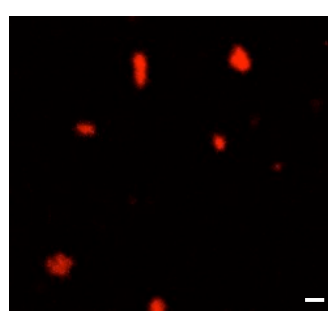

horizontal<smiles>[Y][Y]</smiles>

Fig. 2 Fluorescence labeling of Caco-2 enterocytes by phenylphosphonate-substituted porphyrines.

Fluorescence emission spectra of Caco-2 cells exposed to $p-\mathrm{H}_{8} \mathrm{TPPA}, m-\mathrm{H}_{8} \mathrm{TPPA}(\mathrm{A})$ or the isopropyl-modified phosphonate $p$ - $\mathrm{H}_{8} \mathrm{TPPA}-\mathrm{iPr} 8$ (C) in comparison with each of the phenylphosphonate porphyrins as $10 \mu \mathrm{M}$ dilution in assay buffer $\left(\lambda_{\mathrm{Exc}_{\mathrm{C}}} 416 \mathrm{~nm}\right)$. (B) Confocal images of Caco-2 upon loading with $p$ - $\mathrm{H}_{8}$ TPPA or $m$ $\mathrm{H}_{8}$ TPPA. (D) Confocal images of $p-\mathrm{H}_{8} \mathrm{TPPA}-\mathrm{iPr}_{8}$ in the presence or absence of Caco-2 cells. Scale bar $=10 \mu \mathrm{m}$. Data are representative for three independent experiments. 
Steady-state fluorescence spectra of $p-\mathrm{H}_{8}$ TPPA $/ m-\mathrm{H}_{8}$ TPPAloaded Caco-2 cells exhibit a S1-fluorescence pattern with two-band emission maxima at 655 and $705 \mathrm{~nm}$, almost perfectly matching the fluorescence characteristics of the sensor applied in a physiological buffer (see Fig. 2A). Thus, $p-\mathrm{H}_{8}$ TPPA and $m-\mathrm{H}_{8}$ TPPA seemed to pass the cellular membrane reaching the cell interior intact (see Fig. $2 \mathrm{~A}$ and Suppl Fig. 2), a result further confirmed by confocal microscopic imaging of living enterocytes (see Fig. 2B). We further performed cellular uptake experiments implementing the detergent pluronic F-127, aiming to counterbalance the partial hydrophobic properties of the porphyrin skeleton. Yet, the amphipathic character of $p-\mathrm{H}_{8}$ TPPA and $\mathrm{m}-\mathrm{H}_{8}$ TPPA is sufficient to enable cellular entrance (see Fig. 2A). Aside from the two fluorescent arylphosphonic acids an isopropyldiester-modified variant $\left(p-\mathrm{H}_{8} \mathrm{TPPA}_{\mathrm{T}} \mathrm{iPr_{8 }}\right)$, intentionally blocked for metal binding at the phosphonate moiety, was aimed for Caco-2 cell application. As seen in Fig. $2 \mathrm{C}$, the fluorescence emission output of $p-\mathrm{H}_{8} \mathrm{TPPA}-\mathrm{iPr}$ was much lower in the incubation buffer as well as in the presence of cells. The confocal microscopy pictures depict $p-\mathrm{H}_{8}$ TPPAiPr $r_{8}$ microcrystals of $\sim 20 \mu \mathrm{m}$ size, inaccessible for cellular uptake. Even the presence of the detergent pluronic did not improve the solubility of the diester in aqueous media (see Fig. 2C).
A)

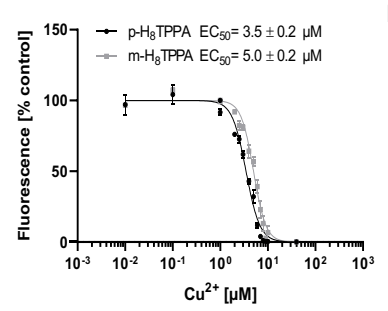

C)

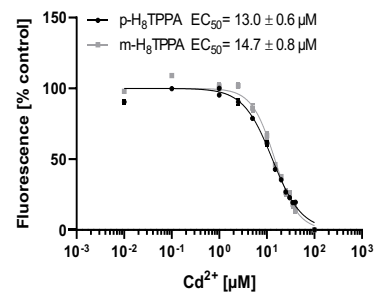

Fig. 3 Fluorescence titration of $p-H_{8}$ THPPA and $m-H_{8}$ TPPA with metal cations quantities of metal cations followed by detection of fluorescence emission $\left(\lambda_{\text {Exc/Em. }} 416 \mathrm{~nm} / 650 \mathrm{~nm}\right)$. Data are means \pm S.E.M. of at least $n=3$ independent experiments. Sigmoidal dose-response curves were fitted by non-linear regression and the resulting $\mathrm{EC}_{50}$ values are indicated.

Addition of $\mathrm{CuSO}_{4}$ caused the most pronounced effects of all metal ions tested. Upon treatment with $40 \mu \mathrm{M} \mathrm{Cu}{ }^{2+}$ almost complete abrogation of $p-\mathrm{H}_{8}$ TPPA and $\mathrm{m}-\mathrm{H}_{8}$ TPPA (final concentrations $10 \mu \mathrm{M}$ ) fluorescence was observed (see Fig. 1C, Suppl Fig. 1 and Fig. $3 \mathrm{~A}$ ). The half maximal effective concentration for $\mathrm{p} / \mathrm{m}-\mathrm{H}_{8}$ TPPA fluorescence silencing was considerably lower for copper than for all the other metal cations tested (see Fig. 3 and Suppl Fig. 4).
$10 \mu \mathrm{M} p-\mathrm{H}_{8}$ TPPA or $m-\mathrm{H}_{8}$ TPPA solutions were treated with increasing
A)

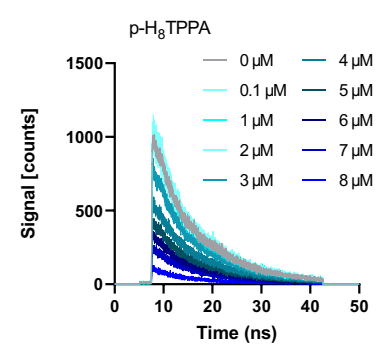

B)

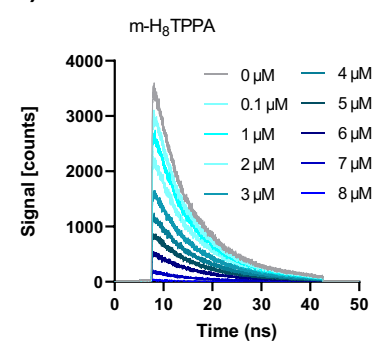

C)

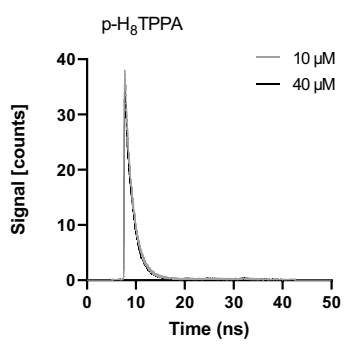

D)

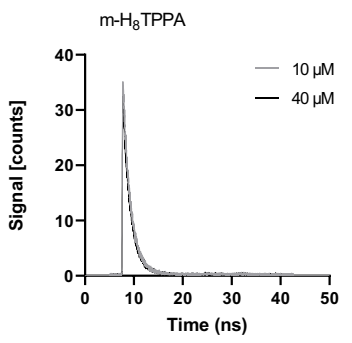

Fig. 4 Fluorescence decay curves of $p-H_{8}$ THPPA and $m-H_{8}$ TPPA in the presence of CuSO

Time-resolved fluorescence was measured on $p-\mathrm{H}_{8}$ THPPA and $m-\mathrm{H}_{8}$ TPPA (each $10 \mu \mathrm{M}$ ) in the presence of various amounts of $\mathrm{CuSO}_{4}$ between 0 and 40 $\mu \mathrm{M}$. $\mathrm{CuSO}_{4}$ was admixed until the actual cupric concentration was reached. Then samples were gently mixed and incubated for 60 seconds before performing time-correlated single photon counting. For 10 and $40 \mu \mathrm{M} \mathrm{CuSO}_{4}$ $(C+D)$ the intensity of the excitation intensity was enhanced by a factor of 8 and measuring time was prolonged by a factor of 10 to improve signal/noise output. Data shown in C+D are scaled differently for direct comparison. Data are representative for one out of three independent experiments.

Time-resolved fluorescence spectroscopy was shown to be highly efficient unraveling interaction mechanisms between fluorescent probes and their surroundings, including specific ions ${ }^{[46,47]}$. It was successfully applied to unravel structural molecular changes that are correlated with fluorescence quenching ${ }^{[48,49]}$. In particular, it allows the quantitative study of dynamic electronic interactions between the fluorescent core and the metal ion to cause a characteristic change in fluorescence intensity and lifetime ${ }^{[50-52]}$. The time-resolved fluorescence showed a dose-dependency in the initial amplitudes of the $p-\mathrm{H}_{8}$ TPPA fluorescence decay curves for $\mathrm{Cu}^{2+}$ at concentrations between 0 and $8 \mu \mathrm{M}$ (Fig. 4A). Noticeably, the time constant was stable for all concentrations. The quantitative fit of the decay curves resulted in 8.3 ns fluorescence lifetime for $p-\mathrm{H}_{8}$ THPPA up to $8 \mu \mathrm{M}$ copper dosing, so at low concentrations of $\mathrm{CuSO}_{4}$ the observed quenching is purely static. At higher $\mathrm{Cu}^{2+}$ concentrations (10-40 $\mu \mathrm{M})$ an increased excitation intensity and prolonged measuring time was needed to improve the signal-to-noise ratio. Under these conditions the copper quenching becomes dynamic (lifetime dropped to $1.7 \mathrm{~ns}$ starting at a concentration of $\mathrm{CuSO}_{4}$ of $10 \mu \mathrm{M}$ ) and/or it is correlated with a molecular change (e.g., oxidation of the molecules), which induces the change of the fluorescence lifetime observed in Fig. 4C. Similar behavior was observed for $m-\mathrm{H}_{8}$ TPPA, which exhibited a constant lifetime of $7.7 \mathrm{~ns}$ up to $8 \mu \mathrm{M} \mathrm{CuSO} 4$ with concomitant drop of the amplitude (Fig. 4B), while above this concentration a pronounced drop 
in lifetime was observed, resulting in $1.6 \mathrm{~ns}$ fluorescence decay time (Fig. 4D).

The assumption of an at least partially irreversible molecule change was further supported by the observation that the copper-induced decrease in $p / m-\mathrm{H}_{8}$ TPPA fluorescence remained almost non-responsive to metal chelator (EDTA or EGTA) posttreatment, whereas for $\mathrm{Zn}^{2+}$ as well as $\mathrm{Hg}^{2+}$ quenching was reversed by both chelators (Fig. 5). Quenching of $p-\mathrm{H}_{8}$ TPPA and $m-\mathrm{H}_{8}$ TPPA fluorescence was observed for $\mathrm{Cu}^{2+}$ and $\mathrm{Cu}^{+}$, irrespective of the oxidation state of copper (Suppl. Fig. 5). This is of importance for future applications, given that copper is present as $\mathrm{Cu}^{+}$in the intracellular milieu, whereas the cupric state $\left(\mathrm{Cu}^{2+}\right)$ predominates in the systemic blood circulation ${ }^{[9,53]}$.

$$
\square \text { Buffer } \square \text { EDTA } \square \text { EGTA }
$$

A)
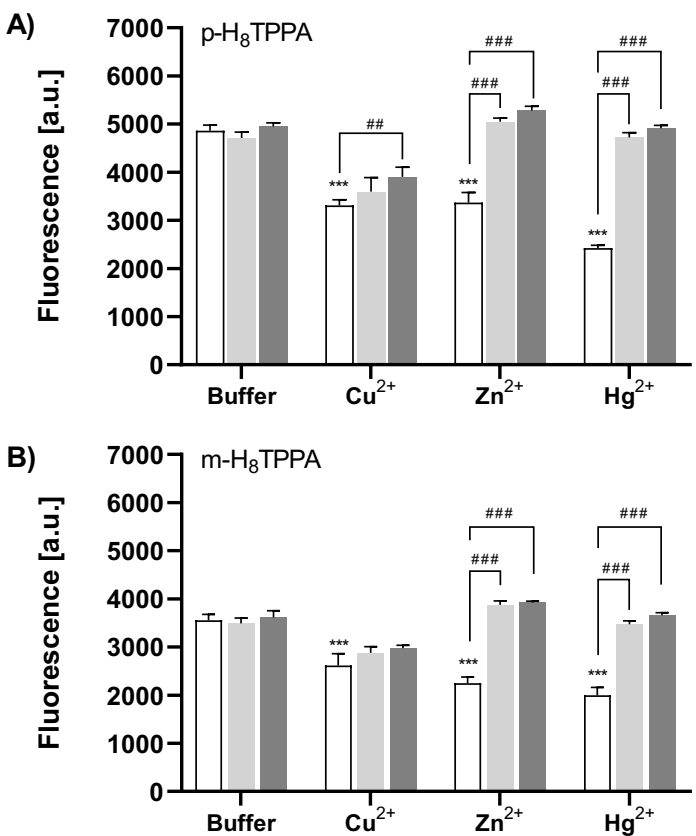

Fig. 5 Reversibility of $p-\mathrm{H}_{8}$ THPPA and $\boldsymbol{m}$ - $\mathrm{H}_{8}$ TPPA metal complexation Fluorescence of metal cation pretreated $p-\mathrm{H}_{8}$ THPPA or $m-\mathrm{H}_{8}$ TPPA solutions upon addition of 50 equivalents of EDTA or EGTA ( Exc/Em. $416 \mathrm{~nm} / 650 \mathrm{~nm}$ ). Data are means \pm S.E.M. of $n=3$ independent experiments. Statistically significant differences from buffer incubation $\left({ }^{* * *} \mathrm{p}<0.001\right.$; two-way ANOVA Tukey post hoc test) or from metal cation treatment (\#\#p<0.01;\#\#\#<0.001; two-way ANOVA/ Tukey post hoc test) are indicated.

When present within Caco- 2 cells, $p-\mathrm{H}_{8}$ TPPA $/ m-\mathrm{H}_{8}$ TPPA fluorescence remained stable upon extracellular addition of $50 \mu \mathrm{M} \mathrm{FeSO}_{4}$ (Fig. 6A), whereas in vitro both sensors were slightly enhanced by iron treatment (Fig. 1). For $\mathrm{Cd}^{2+}, \mathrm{Cu}^{2+}$, $\mathrm{Hg}^{2+} \mathrm{Mn}^{2+}, \mathrm{Pb}^{2+}$ and $\mathrm{Zn}^{2+}$ a $50 \mu \mathrm{M}$ incubation concentration was already shown to be sufficiently high to admit quantitative metal ion delivery into Caco-2 ${ }^{[54-56]}$. The arylphosphonate-tethered porphyrin sensors introduced into the human enterocytes record these incoming metal cations in a fluorescence silencing language (Fig. 6A-C, Suppl. Fig. $6)$.
A)

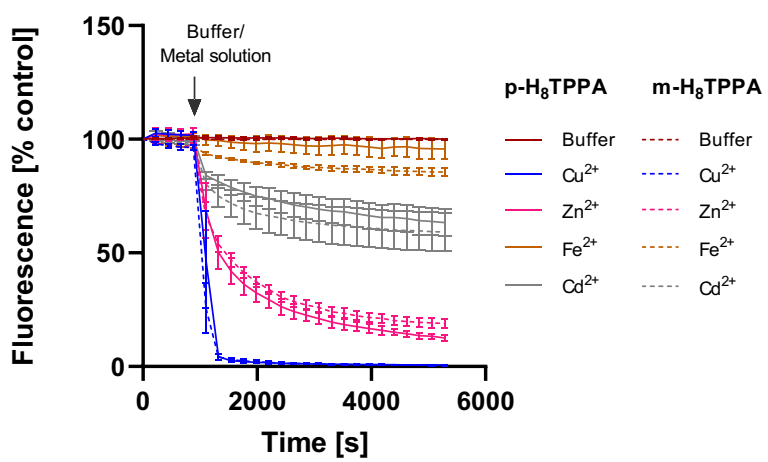

B)

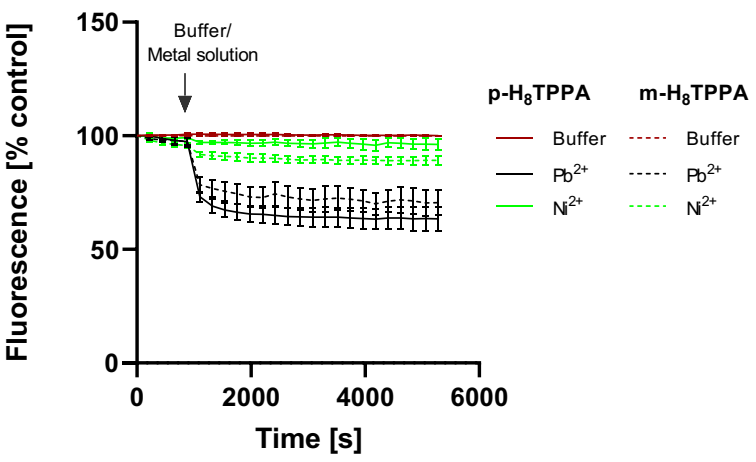

C)

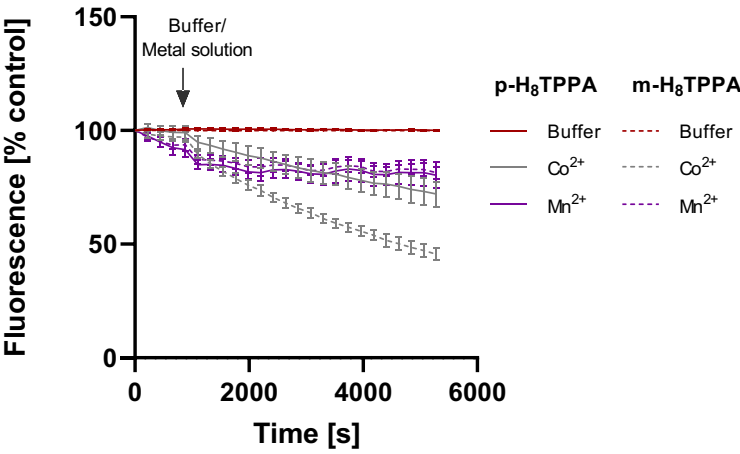

Fig. 6 Live-cell sensing of metal uptake into Caco-2 enterocytes with $p$ $\mathrm{H}_{8}$ THPPA and $m-\mathrm{H}_{8}$ TPPA

Caco-2 cells were loaded with $p-\mathrm{H}_{8}$ THPPA or $m-\mathrm{H}_{8}$ TPPA and the fluorescence recorded in $3 \mathrm{~min}$ intervals ( Exc/Em. $416 \mathrm{~nm} / 650 \mathrm{~nm}$ ). Fifteen minutes after the start of the experiment (arrow), metal cation solutions (final concentration 50 $\mu \mathrm{M})$ or buffer (control) were added and the fluorescence measurement continued. Data are means \pm S.E.M. of $n=3$ independent experiments.

The strong and rapid decline in Caco-2 $p$ - $\mathrm{H}_{8} \mathrm{TPPA} / m$ $\mathrm{H}_{8}$ TPPA fluorescence upon $\mathrm{Cu}$-exposure was somewhat surprising (Fig. 6A) keeping in mind the tight copper buffering ability of the cellular metallochaperons Atox1 (Antioxidant 1 Copper Chaperone), Ccs (Copper chaperone for superoxide dismutase), Cox17 (Cytochrome c oxidase copper chaperone) and glutathione (intracellular GSH concentration around $10 \mathrm{mM}$ ), balancing the pool of cellular labile copper in the femtomolar range ${ }^{[9,57]}$. It can be hypothesized that cellular homeostasis was overburdened by a supraphysiological amount of copper and therefore unable to ensure its correct sequestration. Alternatively, the phenylphosphonic acid porphyrin sensors might detect intracellular protein-complexed copper in addition to free $\mathrm{Cu}^{+}$ ions. The same applies to Zn (Fig. 6A). The free intracellular 
zinc concentration estimated with the fluorescent sensor Zinpyr-1 in Caco-2 cells treated with $50 \mu \mathrm{M} \mathrm{ZnSO}_{4}$ was approximately $2 \mathrm{nM}{ }^{[58]}$. This is several orders of magnitude lower than the concentration required for fluorescence quenching of the phosphonate porphyrins in vitro (Fig. 3B). Irrespective of the actual species causing $p-\mathrm{H}_{8} \mathrm{TPPA} / m$ $\mathrm{H}_{8}$ TPPA quenching, these probes are promising tools to monitor alterations of essential and toxic metals in human body fluids, cell and tissue samples during various life stages and in disease.

\section{Conclusion}

Our design strategy of extending the conjugation of fluorescent core via $\mathrm{sp}^{2}$ bonded phosphonic acids was successful in generating unique metal-responsive fluorescent behavior for each of the studied metal ions. Therefore, as a new class of non-toxic fluorophores, phenylphosphonic acid-functionalized porphyrins provide an expandable and engineerable platform for the development of improved, targeted fluorescence sensors suitable for in vivo applications to determine and visualize metals in tissues during disease progression. This is of utmost importance for diagnostics and in the development and translation of therapeutics for heavy metal intoxication as well as diseases associated with alterations in the homeostasis of essential metal ions.

Note: Experimental section as well as additional UV-Vis, Fluorescent Spectra are available free of charge at Supporting Information section.

\section{Acknowledgements}

G.Y and H.H. would like to thank DFG for funding their work and we would like to thank Dipl.-Ing. Lars Barthel (TU Berlin/Department of Applied and Molecular Microbiology; Prof. Dr. Vera Meyer) for the kind support with the laser scanning confocal microscope.

\section{Conflict of interest}

Authors declare no competing interests.

Keywords: Fluorescence sensors• metals • homeostasis • Caco-2 $\cdot$ Time-Resolved Fluorescence

[1] K. J. Waldron, J. C. Rutherford, D. Ford, N. J. Robinson, Nature 2009, 460, 823-830

[2] C. Andreini, I. Bertini, G. Cavallaro, G. L. Holliday, J. M. Thornton, J. Biol. Inorg. Chem. 2008, 13, 1205-1218.

[3] J. Martínez-Fábregas, S. Rubio, A. Díaz-Quintana, I. DíazMoreno, M. Á. De la Rosa, FEBS J. 2011, 278, 1401-1410.
[4] T. Kambe, T. Tsuji, A. Hashimoto, N. Itsumura, Physiol. Rev. 2015, 95, 749-784.

[5] H. Haase, L. Rink, BioFactors 2014, 40, 27-40.

[6] A. Grubman, A. R. White, Expert Rev. Mol. Med. 2014, 16, e11.

[7] A. W. Wolfgang Maret, Binding, Transport and Storage of Metal lons in Biological Cells, Royal Society Of Chemistry, London, 2014.

[8] J. F. Collins, Molecular, Genetic, and Nutritional Aspects of Major and Trace Minerals, Elsevier Inc., 2016.

[9] J. Kardos, L. Héja, Á. Simon, I. Jablonkai, R. Kovács, K. Jemnitz, Cell Commun Signal 2018, 16, 1-22.

[10] A. R. Bogdan, M. Miyazawa, K. Hashimoto, Y. Tsuji, Trends Biochem Sci 2016, 41, 274-286.

[11] A. E. Nielsen, A. Bohr, M. Penkowa, Biomark. Insights 2006, 1, 99-111.

[12] S. P. Yu, L. M. T. Canzoniero, D. W. Choi, Curr. Opin. Cell Biol. 2001, 13, 405-411.

[13] J. J. Mordang, A. Gubern-Mérida, A. Bria, F. Tortorella, R. M. Mann, M. J. M. Broeders, G. J. den Heeten, N. Karssemeijer, Breast Cancer Res. Treat. 2018, 167, 451458.

[14] S. Norouzi, J. Adulcikas, S. S. Sohal, S. Myers, J. Biomed. Sci. 2017, 24, 87.

[15] J. Lowe, R. Taveira-da-Silva, E. Hilário-Souza, IUBMB Life 2017, 69, 255-262.

[16] A. R. Khan, F. R. Awan, J. Diabetes Metab. Disord. 2014 13, 1-6.

[17] J. Voelkl, R. Tuffaha, T. T. D. Luong, D. Zickler, J. Masyout, M. Feger, N. Verheyen, F. Blaschke, M. Kuro-o, A. Tomaschitz, S. Pilz, A. Pasch, K. U. Eckardt, J. E. Scherberich, F. Lang, B. Pieske, I. Alesutan, J. Am. Soc. Nephrol. 2018, 29, 1636-1648.

[18] A. Vallejo-Illarramendi, I. Toral-Ojeda, G. Aldanondo, A. López de Munain, Expert Rev. Mol. Med. 2014, 16, e16.

[19] A. I. Bush, W. H. Pettingell, G. Multhaup, M. D. Paradis, J. P. Vonsattel, J. F. Gusella, K. Beyreuther, C. L. Masters, R. E. Tanzi, Science (80-. ). 1994, 265, 1464-1467.

[20] P. Zatta, D. Drago, S. Bolognin, S. L. Sensi, Trends Pharmacol. Sci. 2009, 30, 346-355. 
[21] Y. Liu, M. Nguyen, A. Robert, B. Meunier, Acc. Chem. Res. 2019, 52, 2026-2035.

[22] W. Maret, in BioMetals, 2009, pp. 149-157.

[23] C. M. Ackerman, S. Lee, C. J. Chang, Anal. Chem. 2017, 89, 22-41.

[24] K. P. Carter, A. M. Young, A. E. Palmer, Chem. Rev. 2014, 114, 4564-4601.

[25] G. Hong, A. L. Antaris, H. Dai, Nat. Biomed. Eng. 2017, 1, $1-22$.

[26] R. McRae, P. Bagchi, S. Sumalekshmy, C. J. Fahrni, Chem. Rev. 2009, 109, 4780-4827.

[27] E. J. New, V. C. Wimmer, D. J. Hare, Cell Chem. Biol. 2018, 25, 7-18.

[28] E. M. Nolan, S. J. Lippard, Acc. Chem. Res. 2009, 42, 193203.

[29] C. J. Frederickson, Int. Rev. Neurobiol. 1989, 31, 145-238.

[30] S. C. Burdette, G. K. Walkup, B. Spingler, R. Y. Tsien, S. J. Lippard, J. Am. Chem. Soc. 2001, 123, 7831-7841.

[31] X. A. Zhang, D. Hayes, S. J. Smith, S. Friedle, S. J. Lippard, J. Am. Chem. Soc. 2008, 130, 15788-15789.

[32] T. K. Hurst, D. Wang, R. B. Thompson, C. A. Fierke, Biochim Biophys Acta 2010, 1804, 393-403.

[33] H. Bischof, S. Burgstaller, M. Waldeck-Weiermair, T. Rauter, M. Schinagl, J. Ramadani-Muja, W. F. Graier, R. Malli, Cells 2019, 8, 492.

[34] S. J. A. Aper, P. Dierickx, M. Merkx, ACS Chem. Biol. 2016, $11,2854-2864$

[35] J. L. Vinkenborg, T. J. Nicolson, E. A. Bellomo, M. S. Koay, G. A. Rutter, M. Merkx, Nat. Methods 2009, 6, 737-740.

[36] G. Yücesan, Y. Zorlu, C. Brown, C. Keil, M. M. Ayhan, H. Haase, R. B. Thompson, I. Lengyel, Chem. - A Eur. J. 2020, chem.202001613.

[37] M. Maares, M. M. Ayhan, K. B. Yu, A. O. Yazaydin, K. Harmandar, H. Haase, J. Beckmann, Y. Zorlu, G. Yücesan, Chem. - A Eur. J. 2019, 25, $11214-11217$.

[38] K. Nagarajan, K. P. Shelly, R. R. Perkins, R. Stewart, R. J. STEWART Can Chem, Can J Chem 1987, 65, 1729-1733.

[39] C. M. Sevrain, M. Berchel, H. Couthon, P.-A. Jaffrès, Beilstein J. Org. Chem 2017, 13, 2186-2213.
[40] G. Yücesan, Y. Zorlu, M. Stricker, J. Beckmann, Coord. Chem. Rev. 2018, 369, 105-122.

[41] K. Siemensmeyer, C. A. Peeples, P. Tholen, F. Schmitt, B. Çoşut, G. Hanna, G. Yücesan, Adv. Mater. 2020, 32, 2000474.

[42] P. Tholen, Y. Zorlu, J. Beckmann, G. Yücesan, Eur. J. Inorg. Chem. 2020, 2020, 1542-1554.

[43] A. Schütrumpf, A. Duthie, E. Lork, G. Yücesan, J. Beckmann, Zeitschrift für Anorg. und Allg. Chemie 2018, 644, 1134-1142.

[44] P. Tholen, C. A. Peeples, R. Schaper, C. Bayraktar, T. S. Erkal, M. M. Ayhan, B. Çoşut, J. Beckmann, A. O. Yazaydin, M. Wark, G. Hanna, Y. Zorlu, G. Yücesan, Nat. Commun. 2020, 11, 1-7.

[45] N. Venkatramaiah, C. F. Pereira, R. F. Mendes, F. A. Almeida Paz, P. C. Tome, Anal. Chem 2015, 87, 45154522.

[46] F. J. Schmitt, B. Thaa, C. Junghans, M. Vitali, M. Veit, T. Friedrich, Biochim. Biophys. Acta - Bioenerg. 2014, 1837, 1581-1593.

[47] F. J. Schmitt, E. G. Maksimov, H. Suedmeyer, V. Jeyasangar, C. Theiss, V. Z. Paschenko, H. J. Eichler, G. Renger, in Photonics Nanostructures - Fundam. Appl., 2011, pp. 190-195.

[48] F. Velazquez Escobar, T. Hildebrandt, T. Utesch, F. J. Schmitt, I. Seuffert, N. Michael, C. Schulz, M. A. Mroginski, T. Friedrich, P. Hildebrandt, Biochemistry 2014, 53, 20-29.

[49] M. Vitali, D. Bronzi, A. J. Krmpot, S. N. Nikolić, F. J. Schmitt, C. Junghans, S. Tisa, T. Friedrich, V. Vukojević, L. Terenius, F. Zappa, R. Rigler, IEEE J. Sel. Top. Quantum Electron. 2014, 20, 344-353.

[50] J. Märk, F.-J. Schmitt, C. Theiss, H. Dortay, T. Friedrich, J. Laufer, Biomed. Opt. Express 2015, 6, 2522-2535.

[51] J. Märk, F.-J. Schmitt, J. Laufer, J. Opt. 2016, 18, 054009.

[52] V. Tejwani, F. J. Schmitt, S. Wilkening, I. Zebger, M. Horch, O. Lenz, T. Friedrich, Biochim. Biophys. Acta - Bioenerg. 2017, 1858, 86-94.

[53] M. C. Linder, Metallomics 2016, 8, 887-905.

[54] A. Rossi, R. Poverini, G. Di Lullo, A. Modesti, A. Modica, M. L. Scarino, Toxicol. Vitr. 1996, 10, 27-31.

[55] D. I. Bannon, R. Abounader, P. S. J. Lees, J. P. Bressler, Am J Physiol Cell Physiol 2003, 284, 44-50. 
[56] M. Vázquez, M. Calatayud, D. Vélez, V. Devesa, Toxicology 2013, 311, 147-153.

[57] T. D. Rae, P. J. Schmidt, R. A. Pufahl, V. C. Culotta, T. V. O'Halloran, Science (80-. ). 1999, 284, 805-808.

[58] M. Maares, C. Keil, J. Koza, S. Straubing, T. Schwerdtle, H. Haase, M. Maares, C. Keil, J. Koza, S. Straubing, T.

Schwerdtle, H. Haase, Int. J. Mol. Sci. 2018, 19, 2662. 
